UDC: 821.111(71).09-31 Етвуд М.

\title{
MARGARET ATWOOD'S SURFACING: QUEST FOR THE OTHER, FINDING THE SELF
}

\author{
BILJANA VLAŠKOVIĆ ${ }^{1}$ \\ Univerzitet u Kragujevcu, Filološko-umetnički fakultet, \\ odsek za anglistiku, \\ Kragujevac, Srbija
}

U radu se analizira roman Izranjanje Margaret Etvud kao autorkin doprinos razumevanju pojma Drugog, sa posebnim naglaskom na njegovu vezu sa kanadskim identitetom i ženskim iskustvom. Istraživanje je prvenstveno fokusirano na psihoanalitičko i filozofsko zaleđe koje se očitava u glavnim temama romana i otkriva u istim tragove Lakanovih, Levinasovih i Hegelovih razmatranja o pojmu Drugog i drugosti, kao i tragove Huserlovog pojma intersubjektivnosti, odnosno dvojnosti sopstva i drugog. Psihoanalitički i filozofski pristup romanu pokazaće da je Etvud predstavila kanadsku divljinu, jedan od glavnih simbola u njenim delima, kao drugost ili doppelgänger glavne junakinje romana, koja mora da se pomiri sa njom kako bi povratila ono što je izgubljeno: vezu sa Majkom Prirodom, najbitnijim delom karakterističnog 'kanadskog potpisa'.

Ključne reči: M. Etvud, Izranjanje, sopstvo, Drugi/drugost, identitet, ludilo, psihoanaliza, filozofija.

\section{CANADIAN OTHERNESS}

"It seems to me that Canadian sensibility ... is less perplexed by the question 'Who am I?' than by some riddle as 'Where is here?'" - Northrop Frye (1995)

When Margaret Atwood articulated the early settlers' hardships in her 1968 and 1970 poetry collections (The Animals in That Country and The Journals of Susanna Moodie respectively), she made (anadian wilderness the most significant image and yet ambiguous in its role. The early settlers' experience can be compared to that of an archaic man who worshipped the whole of nature as the Triple Goddess, who was seen as the creator of all things and a source of continual rebirth, but also as a fearsome

1 Kontakt podaci (Email): biljanavlaskovic@gmail.com 
power and a bringer of death (see Petrović 1999: 27-41). The same ambivalent feeling towards nature haunted the settlers' imagination, as Atwood described in her poem "Progressive Insanities of a Pioneer":

\author{
He stood, a point \\ on a sheet of green paper \\ proclaiming himself the centre, \\ with no walls, no borders \\ anywhere; the sky no height \\ above him, totally un- \\ enclosed \\ and shouted:
}

\title{
Let me out! (Atwood 1968: 36)
}

Daunted by the inability to determine 'where here is', they tried to ascertain 'what here is' instead, by building borders around them and keeping nature out, rather than keeping with nature. However, the attempts to do without nature proved futile - "it is still no place for an English gentleman", Atwood (1987: 111) has Susanna Moodie say from beneath her grave - and led to a self-induced feeling of otherness in relation to Canadian wilderness, which became a recurrent motif in Atwood's writings, functioning "as geographical location marker, as spatial metaphor, and as Canada's most popular cultural myth" (Howells 1996: 21). In Atwood's novel Surfacing (1972) wilderness is represented as the Canadians' "own distinctive national space" (Ibid.) where, instead of dispensing with it, the unnamed heroine of the novel has to learn to go back to her roots so as to rediscover her Self. This paper explores Surfacing as Atwood's contribution to the understanding of the concept of Other, which she skillfully embedded in her short novel by making it pregnant with meaning. The analysis will show that going back to the roots means becoming one with nature again and resolving the alienation which is created by the separateness between people and nature. Joseph Campbell's stages in the rites of passage, separation - initiation - return, will correspond to Hegelian thesis - antithesis - synthesis and explain the narrator's quest for the appropriate language suitable to describe her new-found Canadian and female identity. Moreover, I will argue that Atwood's perception of otherness as part of 'Canadian signature' is successfully embedded in the novel's main themes and is related to different philosophical concepts of the 0ther, such as those of Jacques Lacan (language and symbolic order), Emmanuel Lévinas (ecstasy and insanity), Hegel (master-slave dialectic), Edmund Husserl (intersubjectivity), etc., covering a whole range of various options for achieving the synthesis between the Self and the 0ther.

\section{MADNESS AS A MIRROR-IMAGE OF OTHERWISE THAN BEING}

Surfacing draws on the modernist stream-of-consciousness technique, which is characterized by the author's disappearance from the text itself and the associative, 
psychological and symbolic internal monologue. But unlike the genuine modernist novels, which usually reinforce the pattern of non-telling (one notable example of this pattern would be the three first-person narrators in Faulkner's The Sound and the Fury who are not actually telling their story to anyone in particular), the narrator of Surfacing is eager to tell her story. The written text of the narrator's thoughts can be best described by Plato's metaphor of a speech that becomes an orphan once it is written down - it is passed on to the readers who should adopt it, but it can also be subject of maltreatment or abuse ${ }^{2}$. The image of the orphan is particularly significant since the novel is abundant with various images of a child yet unborn, having "its eyes open" and looking out "through the walls of the mother's stomach, like a frog in a jar" (Atwood 1982a: 522), signifying the importance of being allowed to be born and set free from 'the jar' which is the womb, both literally and figuratively speaking. The novel begins with a description of a forest stained with images of death and disease and an anxious thought of the narrator: "I can't believe I'm on this road again" (502). The journey initially marks the beginning of one-woman's quest for her lost father, but later proves to be a more intimate quest for her lost identity and her true, rather than imagined, past. In Joseph Campbell's terms, the traditional path of the mythological adventure of the hero is an intensification of the formula represented in the rites of passage: separation - initiation - return: which he named the nuclear unit of the monomyth (Campbell 1975). Thus, the journey to the Quebec bush coincides with the separation of the heroine from the city and the return to the place of her childhood only to become a child again. The novel is titled Surfacing because we can recognize the three stages of psychological progress in the narrator's character (and those three correspond to separation - initiation - return), submersion - ascension - surfacing. Coral Ann Howells (1996: 32) noted that "'Surfacing' is a gerund ..., indicating process and activity rather than a completed action" so that the action is focused on a "change in the narrator's subjective perceptions of reality". 'Surfacing' is in fact the synthesis to be reached at the end of the quest. Howells (2006: 111) states elsewhere that Surfacing is an example of what postmodern literary theorist Linda Hutcheon calls 'historiographic metafiction', an exploration of the relation of history and narrative and the processes of creating history. Furthermore, since Surfacing begins like a detective novel, there are resemblances between the narrator and Carlo Ginzburg's pattern of author and reader as hunters:

Man has been a hunter for thousands of years. In the course of countless chases he learned to reconstruct the shapes and movements of his invisible prey from tracks on the ground, broken branches, excrement, tufts of hair, entangled feathers,

2 In Plato's Phaedrus Socrates says:

I cannot help feeling, Phaedrus, that writing is unfortunately like painting; for the creations of the painter have the attitude of life, and yet if you ask them a question they preserve a solemn silence. And the same may be said of speeches. You would imagine that they had intelligence, but if you want to know anything and put a question to one of them, the speaker always gives one unvarying answer. And when they have been once written down they are tumbled about anywhere among those who may or may not understand them, and know not to whom they should reply, to whom not: and, if they are maltreated or abused, they have no parent to protect them; and they cannot protect or defend themselves. (Plato 1994-2009) 
stagnating odors. He learned to sniff out, record, interpret, and classify such infinitesimal traces as trails of spittle. He learned how to execute complex mental operations with lightning speed, in the depth of a forest or in a prairie with its hidden dangers. (Ginzburg 1989: 102)

This squatting on the ground in search of physical clues changes in due time into a search for the traces of the narrator's Self, hidden in the wilderness of the Quebec bush, which I already identified as the 0ther.

The narrator is accompanied by a married couple, Anna and David, and her boyfriend Joe, all three of whom are necessary at the moment for practical purposes, yet at the same time represent obstacles to her search. She finds, however, still more impediments to her progress along the way: the repressed memories of her always logical father and of her resilient mother, flashes of insight into not so happy a childhood, while at the same time there echo in her mind various dilemmas and musings over many questions - war, religion, divorce, the place of women in the Canadian society, Canadian identity, the attitude towards the Americans, etc. An even more important memory is that of her brother, her anti-Self, or best described by the Jungian term 'shadow'. The narrator and her brother are the Self and anti-Self juxtaposed:

I didn't want there to be wars and death. I wanted them not to exist; only rabbits with their coloured egg houses, sun and moon orderly above the flat earth, summer always, I wanted everyone to be happy. But his pictures were more accurate, the weapons, the disintegrating soldiers: he was a realist, that protected him. (Atwood 1982a: 600)

A dark formless danger is lurking in the shadow that is her brother and brings about serious moral and ethical problems, thus making the ascension even more difficult. On the other hand, only by a re-examination of her past and of her opinions on many moral issues can she discover her own delusion: she realizes that she has been lied to, influenced by the society, and tricked into believing the believable: "I must be more careful of my memories. I have to be sure they're my own and not the memories of other people telling me what I felt, how I acted, what I said" (Atwood 1982a: 578). The gradual realization of a false past leads to an awareness of living in a distorted present: she believed only what she was told to and now each issue had to be re-examined, old opinions rejected and new opinions formed. The process itself resembles a Nietzschean form of therapy, but one which leads the narrator into madness, or an ecstasy as Lévinas (1981: 3) called it in Otherwise Than Being, an ecstasy which cannot negate nor control the otherness but can accept it: "Not to be otherwise, but otherwise than being. And not to not-be; passing over is not here equivalent to dying". She remembers her father saying that "madness is only an amplification of what you already are" (Atwood 1982a: 576) and peacefully accepts the sensation. Her lunacy signifies the beginning of the return phase, or surfacing. It is a fever at the end of a long psychological illness, a fever in which both the body and the mind burn only to become sane again. Her madness is similar to the renaissance notion of madness, described by Foucault (1980: 73) as "an imaginative freedom" allowing one to flourish. 
The climax of the narrator's quest begins with her diving in the lake in search of the Indian paintings, during which she sees "a dark oval trailing limbs. It was blurred, but it had eyes, they were open, it was something I knew about, a dead thing, it was dead" (Atwood 1982a: 608). Finally, the repressed memory of her lost baby is released and she is exposed as conscience-stricken at having aborted her pregnancy. She surfaces literally, letting the water cleanse her and baptize her. According to Jung (1964: 157), "initiation is in essence a process which begins with the ritual of submission; after it, there ensues a period of restraint, which is then followed by a further ritual of liberation". The liberation ritual coincides with her emergence from the abyss of her troubled psyche and she is finally able to restore the balance of her mind. In order to achieve that, she needs isolation and becomes a fugitive from human society trying to find peace in the Canadian wilderness all by herself. Once alone on the island, already plunged deep into madness, the narrator becomes an animal wandering around naked, living in different lairs, eating raw plants, and dreaming about having a child that will be raised in the wild and not taught to speak human language. Her mind is now more than ever overwhelmed with memories of her parents. It is to them that she prays, but to no avail - they "dwindle, grow, become what they were, human. Something I never gave them credit for" (Atwood 1982a: 643). Eventually, she finds salvation in a mirror and what is seen here is Atwood's own version of the Lacanian mirror-stage. Namely, Lacan (1949) stated that human identity is decentred and exemplified this by the 'jubilant activity' of infants the moment they recognize their own image in the mirror: that is the first anticipation of oneself as a unified and separate individual. Lacan (1949: 2) further claimed that "we have only to understand the mirror stage as an identification, the transformation that takes place in the subject when he assumes an image". In this sense, the narrator of Surfacing is 'decentred' and, now regressed to a human animal and a child-like state, sees her otherness in the mirror, "a creature neither animal nor human, furless, only a dirty blanket, shoulders huddled over into a crouch, eyes staring blue as ice from the deep sockets; the lips move by themselves" (Atwood 1982a: 643). This confrontation with the mirror is especially relevant because of her earlier rejection to confront it: "I must stop being in the mirror ... Not to see myself but to see. I reverse the mirror so it's toward the wall, it no longer traps me" (632-633). But the subsequent face-to-face encounter with the mirror shows the heroine's determination to reconcile with her own image. Before this time she was unable to separate the I and the 0ther and was wholly dependent on nature for her survival, whereas now she enters a struggle for pre-eminence and refuses to be a victim.

\section{3. 'OTHER AND I' AS 'MASTER AND SLAVE'}

In Phenomenology of Spirit, Hegel (1998) gave a parable of the master-slave dialectic which is based on the confrontation between the ' $I$ ' and the 'other I'. These two are not only duplications of the 'I' but a duality as well, since one cannot exist without the other. Yet, according to Hegel, there ensues a struggle to death between them as they fight for pre-eminence, without realizing that they cannot achieve self- 
consciousness if one of the two should die 3 . In Surfacing, Atwood portrays Canadian wilderness as that 'other I' from which the narrator had fled a long time ago. But in order to stress the urge to go back to nature and embrace it, Atwood has her heroine back in the bush, where she finally realizes that " $[t]$ he garden is a stunt, a trick. It could not exist without the fence" (Atwood 1982a: 636). As long as she fights the wilderness as storage of some past truth, she cannot erase the delusions she has about her alleged marriage, which was in reality a love-affair with her art professor who forced the abortion on her. Following the Hegelian line, she realizes that "withdrawing is no longer possible and the alternative is death" (644), for if her mirror image dies, she dies too. In an interesting study on Atwood's novel, Annis Pratt (1980: 139-154) defines the archetype of the rebirth journey as it applies to the feminine experience in Surfacing and identifies seven phases of that journey. My current discussion primarily concerns the sixth phase which she named "The Final Descent to the Nadir (of the unconscious)". Pratt (1980: 144) describes the psychological plunge as "taking one to the self beneath self and as likely to lead to madness as to transformation". This 'literary insanity' "can either disintegrate the hero entirely or provide the turning point in her quest" (Pratt 1980: 144). Drawing on this remark, we now need to identify the exact nadir of the narrator's despair: it is the moment when the reality becomes a shape shifter tossing her perception between fantasy and normalcy:

From the lake a fish jumps

An idea of a fish jumps

A fish jumps, carved wooden fish with dots painted on the sides, no, antlered fish thing drawn in red on cliffstone, protecting spirit. It hangs in the air suspended, flesh turned to icon, he has changed again, returned to the water. How many shapes can he take.

I watch it for an hour or so; then it drops and softens, the circles widen, it becomes an ordinary fish again. (Atwood 1982a: 641)

Atwood shows that the transformations of the narrator's psyche are equal to those of the fish she sees. Furthermore, it will be remembered that the narrator is alone in the wilderness which acts as the 0ther and is "a symbol for the world of the unexplored, the unconscious, the romantic, the mysterious and the magical" (Atwood 1982b: 232). In her critical essay on Canadian monsters and the supernatural in Canadian fiction, Atwood (1982b: 229-253) relates the wilderness to the monsters that originally appear in native Indian and Eskimo myths: the wendigo ${ }^{4}$ and Coyote. Both represent "the Monster as Other ... forces outside and ... opposed to the human protagonist" (233). In other words, the landscape which surrounds the narrator is the Monster-as-0ther, an object "against which the human characters measure themselves" (235). It is in

3 For more information on the master-slave dialectic, or lordship and bondage, see especially "Chapter B: SelfConsciousness" of Phenomenology of Spirit (Hegel 1998: 104-139).

4 According to the belief of the Montagnais Indians, " [...] those who die insane without the blessing of a priest become wendigos - werewolves, with nothing human but their form, soulless beings of diabolic strength and cunning that wander for all time seeking only to harm whatever comes in their way" (Atwood 1982b: 233). 
this regard that the reality becomes a shape shifter, a trickster ${ }^{5}$ similar to Coyote who represents the landscape and appears at first as harsh and malevolent, whereas "in fact he is double" and "his nature changes according to the vision of the perceiver" (234). Atwood was interested in the radical change of perception in her other works as well, such as in her very brief, but effective poem which opens her Power Politics (1971):

you fit into me

like a hook into an eye

a fish hook

an open eye

The image of the innocent world of a pair of lovers who fit like 'hook and eye' becomes a disturbing image of the eye of a fish pierced with a fish hook. The deconstruction of the 'hook and eye' image signifies what can happen if the perspective is radically changed and shows the power of words and their multiple or layered meanings. In Surfacing, this is reflected in the narrator's obsession with both power and words. Her unconscious becomes 'the discourse of the Other', ${ }^{6}$ as Lacan put it, and she a speaking animal who must conform to the demands of the natural language, "the other language" (Atwood 1982a: 642).

Finally, the heroine's quest amounts to Husserl's 'intersubjectivity' which she finds in the mirror at the end of the novel. The mirror, Jung (1964: 205) taught, "symbolizes the power of the unconscious to reflect an individual objectively, providing him with the opportunity to see himself in a way he has never seen himself before". By looking in the mirror, she experiences herself as seen by the Other and recognizes the rest of the world as full of subjects, rather than objects, whom she must embrace ("To trust is to let go" (Atwood 1982a: 645)) in order to fulfill her desire to procreate. The end of the quest and the end of the novel are deliberately left open to interpretations, with the narrator's boyfriend Joe searching for her in the bush and calling her name (which is never heard in the novel because she represents all womanhood) while she stands peacefully and ready to assimilate into the society of others after being made one with her own 0ther: her mirror-image, the wilderness, the monsters. To put it more clearly, her surfacing is related to her new-found ability of intersubjective communication which enables her to return to normalcy and the society of other people. For Husserl, "intersubjectivity comes in when we undergo acts of empathy" (Beyer 2011), i.e. when we experience other persons as subjects and not merely objects among other objects. Before the quest, Atwood's narrator could not experience others as individual subjects, hence the need for isolation and deconstruction of her rigidly-formed opinions.

5 Trickster-figure is one of Jung's archetypal figures as defined in Archetypes and the Collective Unconscious. For Jung, trickster is an aspect of the shadow archetype (in Surfacing, the shadow-figure is the narrator's brother), at least in its negative traits. For more insight, see Jung (1981: 255-272).

6 Matthew Sharpe observes: "Freud had already commented in the Introductory Lectures to Psychoanalysis that the unconscious can be compared to a language without a grammar. Lacan (1949) using structuralist linguistics, attempted to systematize this contention, arguing that the unconscious is structured like a language, and that "it speaks"'". 


\section{CONCLUSION}

To summarize, Atwood's fictional study of the concept of 0ther and otherness is largely based on the doppelgänger, or "the dividing of a character in two, each a part of the whole" (Atwood 1982a: 645). In Surfacing, the narrator finds her doppelgänger (or the Monster-as-0ther as I have called it) in the Quebec bush, the place of her childhood, where she goes insane and becomes like a child and a human animal only to become a sane woman in the end. Atwood's treatment of the 0ther (especially in relation to (anadian identity and feminine experience) involves different kinds of 'surfacing': from division to wholeness, from the unconscious to the conscious, from repression to recognition, etc., and enables the heroine to see the world as shared among many individuals, rather than available only to herself. Although she attempted to escape from the monster / Other / wilderness, she ended by returning to it in a desperate attempt to increase self-knowledge and in so doing became one with nature again, gaining strength from it Antaeus-like, which finally makes the story matriarchal in its interest: her own womb was once a hideaway for her unborn baby, it was hiding in her "as if in a burrow", but "instead of granting it sanctuary I let them catch it. I could've said No, but I didn't; that made me one of them too, a killer" (Atwood 1982a: 610). Later she suffers the reverse experience and goes back to nature as a child to its mother's womb, only this time Mother Nature allows the narrator to be reborn.

The novel effectively explores one of the major topics in philosophy: intersubjectivity, or the duality of self and other, with Atwood handling the theme in a way that shows her debt to psychoanalysis (Freud, Jung, Lacan), continental philosophy (Hegel, Husserl, Lévinas, etc.) and Indian folklore and mythology. As I have shown, the structural triplet submersion - ascension - surfacing coincides with the stages of a mythical quest: initiation - separation - return, where the final elements of the triplets (surfacing/return) represent the synthesis of the narrator's Self and her Other, crucial to a person's assimilation into the society of other human beings. In addition to all this, Atwood incorporated the question of the specific 'Canadian signature' in her study by making Canadian wilderness "the symbolic representation of an absent person, a signifier of presence which inevitably draws attention to absence" (Howells 1996: 20). In the narrator's words, she was not complete without the wilderness: "The other half, the one locked away, was the only one that could live; I was the wrong half, detached, terminal. I was nothing but a head, or, no, something minor like a severed thumb; numb" (Atwood 1982a: 582). Ultimately, Surfacing, as a study of otherness, answers the Canadian riddle ('Where is here? What is here?'), which is, contrary to expectations, not a geospatial question, but a question of one's identity. 


\section{REFERENCES}

Atwood, M. 1987. Selected poems, 1965-1975, vol. 1. Boston: Houghton Mifflin Harcourt. Atwood, M. 1968. The Animals in That Country. Toronto: 0xford University Press.

Atwood, M. 1970. The Journals of Susanna Moodie: Poems. Toronto: Oxford University Press.

Atwood, M. 1971. Power Politics. Toronto: House of Anansi Press.

Atwood, M. 1982a. Surfacing. Seven Contemporary Short Novels, eds. C. Clerc \& L. Leiter. Illinois: Scott, Foresman and Company.

Atwood, M. 1982b. Canadian Monsters: Some Aspects of the Supernatural in Canadian

Fiction. Second Words, Selected Critical Prose. Toronto: House of Anansi Press, 229253.

Beyer, C. 2011. Edmund Husserl. The Stanford Encyclopedia of Philosophy (Summer 2011 Edition), ed. E. Zalta). [Internet]. Available at: http://plato.stanford.edu/entries/ husserl/\#EmpIntLif [13.07.2011].

Campbell, J. 1975. The Hero With a Thousand Faces. London: Abacus.

Frye, N. 1995. The Bush Garden: Essays on the Canadian Imagination. Toronto: House of Anansi Press.

Fuko, M. 1980. Istorija ludila u doba klasicizma. Beograd: Nolit.

Ginzburg, C. 1989. Clues: Roots of an Evidential Paradigm. In Clues, Myths, and the Historical Method. Baltimore: The Johns Hopkins UP, 96-125.

Hegel, G. W. F. 1998. Phenomenology of Spirit. New Delhi: Motilal Banarsidass Publishers. Howells, A. C. 1996. Margaret Atwood. London: Macmillan Press Ltd.

Howells, A. C. 2006. Writing History from The Journals of Susanna Moodie to The Blind Assassin. In T. Kozakewich and J. Moss (eds.) Margaret Atwood: The Open Eye. Ottawa: University of Ottawa Press, 107-121.

Jung, C. G. 1964. Man and his Symbols. London: Aldus Books Limited.

Jung, C. G. 1981. On the Psychology of the Trickster-Figure. Archetypes and the Collective Unconscious. Princeton: Princeton UP, 255-272.

Lacan, J. 1949. The mirror stage as formative of the function of the I as revealed in psychoanalytic experience. [Internet]. Available at: http://www.acsu.buffalo. edu/ erikconr/courses/DMS_259/readings/05_LacanMirrorStage.pdf [10.07.2011].

Lévinas, E. 1981. Otherwise than being: or, Beyond essence. The Netherlands: Kluwer Academic Publishers.

Petrović, L. 1999. Quest Myth in Medieval English Literature. Niš: Izdavačka jedinica Univerziteta u Nišu.

Plato, 1994-2009. Phaedrus. [Internet]. Available at: http://classics.mit.edu/Plato/ phaedrus.html [13.07.2011].

Pratt, A. 1980. Surfacing and the Rebirth Journey. In A. Davidson \& C. Davidson (eds.) The Art of Margaret Atwood, Essays in Criticism. Toronto: House of Anansi Press, 139-154.

Sharpe, M. 2005. Jacques Lacan. Internet Encyclopedia of Philosophy. [Internet]. Available at: http://www.iep.utm.edu/lacweb/ [12.07.2011]. 


\section{SUMMARY}

\section{MARGARET ATWOOD'S SURFACING: QUEST FOR THE OTHER, FINDING THE SELF}

The paper examines Margaret Atwood's novel Surfacing as her contribution to the understanding of the concept of Other, especially in relation to Canadian identity and feminine experience. The research is primarily focused on the psychoanalytical and philosophical background of the novel and discovers in it traces of Lacan's, Lévinas', and Hegel's works on the idea of Other and otherness, as well as Husserl's intersubjectivity, or the duality of Self and Other. The psychoanalytical and philosophical approach will show that Atwood portrayed her main character as having a doppelgänger/the 0ther in Canadian wilderness, a major symbol in Atwood's works, with which the narrator of the novel must reconcile and in so doing reconnect with what was lost, i.e. the bond with Mother Nature, the foremost part of the characteristic Canadian signature.

KEYWORDS: M. Atwood, Surfacing, Self, Other/otherness, identity, madness, psychoanalysis, philosophy.

(Original scientific paper received 12.01.2011;

revised 12.07.2011

accepted 01.12.2011) 